\title{
CERPEN-CERPEN KOMPAS 1970-1980 DALAM HEGEMONI NEGARA ORDE BARU (ANALISIS WACANA KRITIS)
}

\author{
Apri Damai Sagita Krissandi \\ PGSD, Univ. Sanata Dharma Yogyakarta \\ Email: apridamai@gmail.com
}

\begin{abstract}
Abstrak
Penelitian ini bertujuan untuk mengetahui ideologi negara dan Kompas pada masa Orde Baru tahun 1960-1980. Selain itu,untuk mengetahui ideologi-ideologi yang terdapat dalam cerpen-cerpen Kompas dan mengetahui posisi cerpen-cerpen Kompas dalam hegemoni negara Orde Baru. Metode penelitian yang digunakan menggunakan metode analisis wacana kritis. Analisis wacana kritis untuk selanjutnya disebut AWK dipakai untuk mengungkapkan hubungan ilmu pengetahuan dan kekuasaan. Teori yang dipakai dalam penelitian ini adalah teori hegemoni Gramsci yang menekankan pentingnya ide dalam kontrol sosial politik dan analisis wacana kritis untuk menganalisis teks secara mendalam melalui konteks. Cerpen memiliki posisi yang unik dalam hubungannya dengan intervensi negara terhadap karya sastra. Cerpen seolah-olah menjadi bagian dari suatu media cetak atau surat kabar yang terhegemoni langsung oleh negara, dalam hal ini Kompas, tetapi pada dasarnya cerpen terpisah secara bentuk. Pada posisi demikian, cerpen memiliki keuntungan, cerpen tidak terhegemoni langsung oleh negara. Counter hegemoni yang dilakukan cerpen merupakan penyeimbang pers sebagai media massa yang ditekan oleh negara. Terbukti dari keempat cerpen yang dianalisis, terdapat kompleksitas dan pluralitas ideologi yang terbangun dari hubungan tokoh-tokoh cerita. Cerpen-cerpen tersebut memperlihatkan adanya pertarungan ideologi. Pertarungan ideologi tersebut yang sebenarnya dialami masyarakat Indonesia pada saat itu.
\end{abstract}

Kata kunci: hegemoni, ideologi, kompas, cerpen

\begin{abstract}
The objectives of this research are to understand the country's hegemony in the Kompas short stories compilation, Dua Kelamin bagi Midin, and the impacts of country's hegemony in it. This research uses a dialectic method. This method has been used to analyse six short stories in the short stories compilation through social contextual aspects. This research uses Gramsci's hegemony theory which emphasizes the importance of idea in social politics control and critical discourse analysis to analyze text intensively through historical context. Short stories have a unique position in its corelation to the country's intervention in literatures. Short stories become a part of mass media or newspaper hegemonied by a country. On that position, short stories have some benefits and they are not hegemonied directly by a country. Short stories hegemony helps mass media to balance news dealing with some mass media which get pressure from country. The six analyzed short stories prove that there is ideological plurality and complexity built in the characters relationships in the stories. It shows that there are social criticisms to the country.
\end{abstract}

Keywords: hegemony, short story, Kompas, ideology

\section{Pendahuluan}

Cerpen adalah salah satu karya sastra yang banyak diakses oleh masyarakat Indonesia. Hal ini terjadi karena cerpen selalu menghiasi surat-surat kabar harian. Dalam satu minggu, sekurang-kurangnya satu kali surat kabar harian memuat cerpen. Perkembangan karya sastra khususnya cerpen yang dipublikasikan para pengarang melalui media cetak sekarang ini mengalami pertumbuhan yang semakin banyak dan diperhitungkan keberadaannya. Pada era ini pulalah, cerita pendek Indonesia menunjukkan fenomena yang sangat spesifik. Hampir seluruh media di Indonesia, mulai dari koran, tabloid, majalah, serta jurnal, menyisipkan cerita pendek sebagai bagian yang cukup penting. Cerita pendek merupakan suatu alat komunikasi dari perasaan-perasaan yang dimiliki manusia. Cerpen merupakan gambaran kehidupan masyarakat yang dinyatakan dalam sebuah 
tulisan, yaitu seperti masalah kemanusiaan, cinta, harapan, protes, ketimpangan sosial, religiusitas, dan sebagainya. Cerpen adalah salah satu genre sastra yang selalu dikaitkan identitasnya sebagai sastra koran, yaitu produk sastra yang muncul di media massa cetak koran, di Indonesia

Salah satu contoh adalah Kompas. Surat kabar Kompas selalu memberikan ruang untuk budaya dan sastra. Walaupun ruang sastra terbatas, Kompas selalu menyajikan dan menyediakan potensi penyegaran sastra yang tidak kecil.

Cerpen-cerpen Kompas seperti sebuah cermin yang membuat pembaca dapat melihat wajah Indonesia yang buram tertutup nodanoda polemik politik yang semakin tidak jelas alurnya. Cerpen-cerpen Kompas dipandang sebagai ukuran umum dalam penulisan cerpen Indonesia yang juga merangsang sejumlah pakar selain untuk menyinisi, mengkritik, atau hendak menandinginya. Akan tetapi, bagaimanakah posisi cerpen-cerpen Kompas jika berhadapan dengan hegemoni negara? Apakah berhadap-hadapan atau justru menjadi corong negara? Mengingat peran negara yang dominan termasuk kontrol yang berlebihan terhadap pers pada masa Orde Baru. Hal ini ditandai oleh peristiwa Malari 1974 yang dinilai krusial dalam performance pers di masa Orde Baru.

Analisis wacana yang dimaksudkan dalam penelitian ini adalah sebagai upaya pengungkapan maksud tersembunyi dari subjek (penulis) yang mengungkapkan suatu pernyataan. Pengungkapan dilakukan dengan menempatkan diri pada posisi penulis dengan mengikuti struktur makna dari sang penulis sehingga bentuk distribusi dan produksi ideologi yang disamarkan dalam karya sastra dapat diketahui. Jadi, wacana dapat dilihat dari bentuk hubungan kekuasaan (hegemoni) terutama dalam pembentukan subjek dan tindakan representatif.

Analisis wacana kritis dapat mengungkap politik yang tersembunyi dalam atau di balik wacana/diskursus yang secara sosial dominan dalam masyarakat, misalnya dalam sistem kepercayaan, agama, peraturanperaturan adat dan interpretasi atau cara pandang masyarakat tentang dunia. Melalui analisis wacana kritis, penulis berusaha mengungkap motivasi dan politik yang berada di balik argumen-argumen yang membela atau menentang suatu metode, pengetahuan, nilai, atau ajaran tertentu. Melalui upaya-upaya itu analisis wacana kritis berkeinginan untuk membangun informasi dan kesadaran yang lebih baik akan kualitas atau keterbatasan dari masing-masing metode, pengetahuan, nilai, atau ajaran tersebut. Percaturan atau aktivitas yang dilakukan berdasarkan hasil pengungkapan tersebut diharapkan menjadi lebih bermutu karena lepas dari kekaburan atau pengelabuan. Analisis wacana kritis juga memiliki agenda untuk mengoreksi bias-bias yang terjadi akibat politisasi dan mengikutsertakan minoritas yang biasanya tersingkirkan atau bahkan disingkirkan dari wacana.

Teori hegemoni penting dalam analisis ini dikarenakan teori hegemoni membantu mengungkap konstelasi kekuasaan yang ada dalam teks cerpen. Melalui teori hegemoni dapat diketahui bentuk-bentuk hegemoni, penyebab hegemoni, dan dampak hegemoni yang terdapat dalam cerpen.

\section{Ideologi Kompas: Dari Populisme Menjadi Birokratisme (1966-1980)}

Perbincangan mengenai pers tidak dapat dipisahkan dari kepentingan yang ada di balik pers tersebut, khususnya kepentingan terhadap informasi yang disampaikan. Di dalam perkembangan pers mutakhir, setidak-tidaknya ada dua kepentingan utama di balik pers, yaitu kepentingan ekonomi dan kepentingan kekuasaan, yang membentuk isi pers, informasi yang disajikan, dan makna yang ditawarkannya. Di antara dua kepentingan tersebut, ada kepentingan lebih mendasar yang justru terabaikan, yaitu kepentingan publik. Pers yang seharusnya berperan sebagai ruang publik, disebabkan oleh kepentingan-kepentingan di atas, justru mengabaikan kepentingan publik itu sendiri. 
Kuatnya kepentingan ekonomi dan kekuatan politik inilah yang sesungguhnya menjadikan pers tidak dapat netral, jujur, adil, objektif dan terbuka. Akibatnya, informasi yang disuguhkan oleh pers telah menimbulkan persoalan objektivitas pengetahuan yang serius pada pers itu sendiri. Kepentingankepentingan ekonomi dan kekuasaan politik akan menentukan apakah informasi yang disampaikan oleh sebuah pers mengandung kebenaran dan kebenaran palsu; menyampaikan objektivitas atau subjektivitas; bersifat netral atau berpihak; mempresentasikan fakta atau memelintir fakta; menggambarkan realitas atau menyimulasi realitas (Piliang, 2005:214).

Pada tahun 1966, sikap kritis pers ini mulai terlihat jelas, ketika ia menanggapi keluhan-keluhan masyarakat atas krisis ekonomi yang parah di awal tahun 1966, terutama masalah kelangkaan barang dan naiknya harga barang dan naiknya bahan-bahan kebutuhan pokok.

Sikap kritis pers Indonesia semakin meningkat di tahun 1967. Sikap kritis pers ini dimanifestasikan, terutama ke dalam dua hal, yaitu pertama mengkritik serta mengecam aktivitas korupsi yang semakin fenomenal dalam birokrasi Negara, kedua menyatakan dukungan kritis dan kreatif terhadap pemerintahan Orde Baru yang baru bangkit.

Tahun 1973 adalah tahun yang panas, tahun penuh keprihatinan, di mana tuntutan tentang perlunya pemerataan pembangunan dan perhatian atas keadilan sosial semakin sering disuarakan, dan begitu juga masalah strategi pembangunan, bantuan, dan modal asing (terutama modal dari Jepang), dan juga korupsi serta penyelewengan negara. Sementara itu, reaksi atas tuntutan masyarakat, termasuk pers, semakin negatif, represif dan keras dari pemerintah Orde Baru (Abar, 1995:141)

Tuntutan masyarakat tentang pemerataan pembangunan dan keadilan sosial disuarakan pers secara kritis dan berani. Begitu pula kritik dan kecaman terhadap persoalan strategi pembangunan, bantuan dan modal asing, pribumi-non-pribumi, serta korupsi dan penyelewengan uang negara dikemukakan pers secara kritis dan berani. Hal ini menunjukkan bahwa pers pada waktu itu tidak terpengaruh oleh reaksi negatif, represif, dan keras dari pemerintah Orde Baru.

Puncaknya adalah terjadinya peristiwa Malari. Salah satu buntut Malapetaka 15 Januari (Malari) 1974, adalah pembredelan 12 pers Indonesia, sebuah bencana yang paling besar bagi pers Indonesia selama pemerintahan Orde Baru, sekaligus awal bangkitnya sifat elit-birokratis dan retoris-normatif dalam pers Indonesia. Dalam konteks inilah peristiwa Malari menjadi suatu batas demarkasi antara pers populis dengan pers elit-birokratis, dan antara pers yang kritis dan pers yang retoris-normatif (Abar, 1995:150).

Hari-hari menjelang peristiwa Malari, pers Indonesia masih bersikap kritis. Misalnya, pada tajuk "Harap Pemerintah Wajar Saja" yang diturunkan oleh harian Kompas berikut:

“... Anjuran untuk hidup sesuai kewajaran sosial tidak akan mungkin terwujud tanpa dibarengi usaha-usaha pemberantasan korupsi. Dan korupsi mudah terjadi, karena ketaklaksanaan yang acak-acakan, di samping menipisnya kesadaran sosial.

Peraturan untuk membatasi masuknya barang-barang mewah akan percuma saja, kalau kepincangan-kepincangan tersebut masih tetap berlangsung. Apalagi kalau suara-suara resmi untuk membendung segala macam kemewahan itu hanya sekedar untuk 'menenangkan' dan 'mendinginkan' gejolak masyarakat dewasa ini.

... Hal itu dikemukakan untuk sekedar mengingatkan agar pemerintah tetap wajar saja dalam usahanya memerangi kemewahannya sekarang ini. Tidak perlu overacting!.... " (Kompas dalam Abar, 1995: 153).

Beberapa hari setelah peristiwa Malari, khususnya setelah sejumlah koran dibredel, populisme dan sikap kritis pers pun mulai memudar. Semakin jauh ditarik ke muka dari peristiwa Malari, akan semakin terlihat jelas proses pemudaran populisme dan sikap kritis 
pers, dan sebaliknya, akan semakin terlihat jelas proses peningkatan sikap elistis-birokratis dan retoris-normatif. Pers lebih banyak menunjukkan dukungan dan persetujuan atas setiap kebijakan yang dibuat oleh negara, serta lebih suka mengutip retorika-retorika politik pejabat tinggi negara untuk digarisbawahi, ditegaskan, dan diperkuat. Tidak pernah lagi terdengar kritik, kecaman ataupun protes dari pers terhadap kebijakan yang dibuat negara atau terhadap retorika dan tindakan politik pejabat tinggi negara yang dianggap tidak sesuai dari kehendak dan aspirasi masyarakat. Dengan kata lain, pers Indonesia pasca Malari ini adalah pers yang afirmatif(Abar, 1995:153).Kompas bukan termasuk surat kabar yang dibredel. Oleh karena itu, sikap kritis yang awalnya ditunjukkan Kompas mulai memudar dan bahkan menjadi elistis-birokratis dan retoris-normatif.

Tak mengherankan jika pakar sejarah dan politik Indonesia, Benedict R.O'G Anderson, dari Universitas Cornell, yang menulis bukubuku bermutu tentang nasionalisme dan Asia Tenggara, antara lain Java in a time of revolution: occupation and resistance 1944-1946 dan Imagined Communities: Reflections on the Origin and Spread of Nationalism, memandang peranan Kompas dengan kritis. Anderson menyebut Kompas sebagai koran yang sangat Orde Baru (New Order's newspaper par exellence). Kompas sangat kompromistis terhadap rezim Presiden Soeharto. Tekanan pemerintahan Soeharto berlangsung sangat efektif dalam diri Kompas, sehingga menghasilkan gaya penulisan yang penuh kehati-hatian. Pembaca Kompas diajak berputar-putar dulu ketika membaca berita atau opini Kompas.

Itulah strategi Kompas untuk menyiasati kekuasaan hegemonik Orde Baru, agar bisa bertahan hidup, juga untuk menyelamatkan perut ribuan karyawan yang jadi tanggungannya. Namun, sah saja jika Benedict Anderson menafsirkan strategi tadi adalah tanda tunduknya Kompas terhadap kekuasaan Orde Baru.

Koran sebagai lembaga memiliki kelebihan sekaligus kelemahan. Kelemahan itu akan dengan mudah dapat ditangkap, apabila dibandingkan antara kelebihan dan kelemahan orang-seseorang dengan suatu lembaga. Orang-seseorang cenderung lebih bebas, lebih lincah, lebih segar, lebih cekatan. Lembaga tak lepas dari birokrasi, cenderung lamban, cenderung banyak pertimbangan dan hambatan, cenderung tidak lincah menangkap aktualitas serta menangkapnya secara aktual pula (Oetama, 2001:197).

\section{Ideologi-Ideologi di Dalam Cerpen Kom- pas (1970-1980)}

Sebagian besar cerpen-cerpen yang diterbitkan Kompas merupakan cerpen-cerpen yang mengangkat tema-tema sosial-politik. Semangat dan misinya pun bersifat humanis. Sepanjang sejarah kesusastraan Indonesia, cerpen-cerpen yang mengangkat tema sosialpolitik memang tidak pernah habis ditelan zaman. Akan tetapi, muatan pesan yang terkandung dalam cerpen Kompas terasa seperti sebuah sastra propaganda yang berusaha menggiring opini publik ke arah perubahan yang lebih baik. Kepiawaian para pengarang dalam meleburkan peristiwa faktual dan aktual dalam cerpen-cerpen pilihan ini mampu memberikan gambaran kondisi bangsa saat itu.

Adapun cerpen-cerpen yang dijadikan data adalah cerpen-cerpen Kompas 1970-1980 (Juara Drum Band, Tawanan, Pablawan, dan Mogok). Gramsci menyebutkan bahwa manusia adalah subjek, fakta yang mengubah sejarah. Dalam wilayah teks, manusia muncul dalam tokohtokoh cerita, dalam hal ini tokoh-tokoh dalam cerpen Juara Drum Band karya Yusakh Ananda, cerpen Tawanan karya Tahi Simbolon,cerpen Pablawan karya Zakaria M. Passe, dan cerpen Mogok karya F. Rahardi.

Cerpen-cerpen tersebut dapat mewakili konteks pertarungan ideologi dekade 19701980. Dekade 1960-1970 merupakan tahuntahun yang bersejarah bagi pers Indonesia. Peristiwa Malari pada tahun 1974 adalah "batas air" atau titik tolak performance pers di masa Orde Baru. Pers pra-Malari adalah pers idealis, pers yang menyuarakan hati nurani dan aspirasi 
rakyat, pers yang berani dan kritis melakukan kontrol sosial. Pers pra-Malari adalah pers yang bebas, merdeka, serta artikulatif. Sebaliknya, pers post-Malari adalah pers yang tidak atau kurang idealis, cenderung "mewakili" kepentingan penguasa, pemerintah atau negara, serta jarang bahkan tidak pernah melakukan kontrol sosial secara kritis, tegas, dan berani. Pers post-Malari adalah pers yang tidak bebas, atau paling tidak pers yang memiliki kemerdekaan yang amat terbatas. Performance pers post-Malari di tahun 80an hingga sekarang pun belum menunjukkan perubahan yang fundamental. Pers masih cenderung menjadi pres release pemerintah (Anwar dalam Abar, 1995: 5). Keempat cerpen tersebut dianggap ideologis, memposisikan diri dengan sadar untuk menghadapi suatu posisi lain. Keempat cerpen tersebut dapat memperlihatkan keinginan pengarang untuk lepas dari intervensi pemerintah pasca-peristiwa Malari. Keempat cerpen tersebut dapat mewakili keadaan zamannya, selain itu keempat cerpen tersebut merupakan sampel bertujuan, yaitu dipilih atas dasar kesesuaian dengan realiatas politik maupun sosial masyarakat Indonesia pada tahun 1966-1980.

Keempat cerpen yang dianalisis mempunyai kompleksitas dan pluralitas ideologi yang terbangun dari hubungan tokoh-tokoh cerita. Cerpen-cerpen tersebut memperlihatkan adanya pertarungan ideologi. Sebagian ideologi yang muncul dalam cerpen dapat mewakili kelas dominan, yaitu negara, ideologi yang lain adalah suara pengarang yang mewakili kelas subaltern, yaitu masyarakat. Hal ini juga memperlihatkan bahwa ideologi-ideologi yang tampil dalam keempat cerpen yang dijadikan sampel, merupakan representasi pertarungan ideologi yang terjadi dalam masyarakat Indonesia pada tahun 1960-1980.

Pluralitas ideologi yang ditemukan dalam keempat cerpen yang dijadikan sampel adalah sebagai berikut: militerisme, komunisme, teisme, seksualisme, humanisme, feminisme, realisme, otoritarianisme, materialisme, dan kapitalisme. Hanya saja, seperti tampak pada data, pluralitas ideologi itu tidaklah sama porsinya. Ada ideologi yang dominan, ada yang kurang dominan, dan ada pula yang tidak dominan. Yang paling dominan adalah militerisme, disusul oleh kapitalisme, otoritarianisme, materialisme, humanisme, komunisme, realisme, feminisme, teisme, seksualisme.

Ideologi-ideologi tersebut diklasifikasikan berdasarkan ideologi yang mewakili negara atau kelas hegemonik dan hegemoni yang mewakili rakyat sebagai counter hegemoni. Ideologi yang mewakili negara adalah militerisme, kapitalisme, otoritarianisme, materialisme, seksualisme. Sedangkan Ideologi yang mewakili rakyat adalah humanisme, realisme, feminisme, teisme, dan komunisme. Pembagian tersebut didasarkan atas pertarungan ideologi yang terdapat dalam cerpen-cerpen tersebut. Ideologi yang mewakili rakyat adalah suara pengarang yang disisipkan lewat hubungan tokoh-tokoh cerita dalam cerpen untuk melawan ideologi-ideologi penguasa atau negara.

Cerpen Juara Drum Band karya Yusakh Ananda mengandung ideologi militerisme, komunisme, humanisme, nasionalisme, dan teisme. Cerpen Juara Drum Band bercerita tentang keadaan suatu bangsa yang baru saja menikmati kemenangan dari suatu peperangan. Sebagai pengarang, Yusakh Ananda adalah seorang yang kritis, hal ini terlihat dari cerpen Juara Drum Band yang sarat dengan kritik. Dari kesehariannya yang sederhana, dan lewat cerpen-cerpennya dapat diketahui bahwa Yusakh Ananda menyuarakan tentang humanisme dan nasionalisme. Kepeduliannya terhadap keadaan yang terjadi memunculkan sikap kritis, misalnya lewat cerpen-cerpennya ia menentang ketidakadilan yang terjadi akibat militerisme.

Dalam Cerpen Tawanan karya Parakitri Tahi Simbolon terdapat empat ideologi, yaitu seksualisme, humanisme, feminisme, dan militerisme. Ideologi-ideologi tersebut muncul dalam hubungan antar tokoh-tokohnya, misalnya tokoh saya yang adalah seorang anggota komando aksi yang berfungsi membantu tugas tentara dalam penumpasan PKI. Para anggota komando aksi ini berisi para pencoleng dan 
berandal yang berpura-pura menjadi pahlawan. Komando aksi tersebut adalah penggambaran dominan dari ideologi militerisme.

Lewatcerpen Tawanan Parakitriberusaha mengkritik kekejian masyarakat Indonesia terhadap PKI. Ia memandang bahwa perlakuan keji terhadap orang-orang PKI sangat tidak adil dan tidak manusiawi. Parakitri menunjukkan fakta realitas bahwa kekejaman perkosaan massal dan pembunuhan yang dilakukan tentara dan komando aksi terhadap orang-orang Lekra sangat biasa. Kekejian tersebut telah menjadi kebiasaan. Matinya naluri kemanusiaan tersebut yang diperjuangkan oleh Parakitri. Hal tersebut mencerminkan ideologi humanis yang terdapat dalam diri Parakitri. Selain Humanis, Parakitri juga menyuarakan feminisme lewat tokoh Kemala yang terdapat dalam cerpen Tawanan.

Cerpen Pablawan karya Zakaria M. Passe juga menunjukkan adanya kompleksitas ideologi. Ideologi-ideologi yang muncul dalam cerpen adalah materialisme, realisme, humanisme, dan otoritarianisme. Materialisme diwakili oleh tokoh pahlawan yang tidak segansegan melakukan kecurangan, salah satunya adalah praktik nepotisme. Realisme diwakili oleh tokoh Masdul, dan otoritarianisme diwakili oleh tokoh raja yang bersikap otoriter.

Sebagai seorang wartawan, Zakaria tentunya mempunyai sikap kritis. Ia menjadi responden Tempo sejak pertama kali terbit. Majalah Tempo tergolong majalah yang kritis terhadap pemerintah. Hingga terjadi Malari yang mengakibatkan dibredelnya majalah Tempo. Sikap kritis tersebut masih terdapat dalam diri Zakaria M. Passe. Hal ini dapat dilihat dari cerpennya yang berjudul Pablawan. Lewat tulisan-tulisannya dapat diketahui Zakaria menyuarakan humanisme sebagai dasar naluri untuk selalu bersikap kritis.

Cerpen Mogok karya F. Rahardi mempunyai ideologi kapitalisme, humanisme, dan sosialisme. Cerpen ini menceritakan sekelompok ayam yang mogok bertelur karena ingin menuntut hak-hak mereka dalam hal kesejahteraan makanan. Kapitalisme ditunjukkan oleh peternak yang hanya mempedulikan keuntungan yang sebesarbesarnya tanpa mempedulikan kesejahteraan ayam-ayamnya, sedangkan komunisme ditunjukkan oleh ayam-ayam yang membentuk serikat untuk berjuang demi hak mereka dengan cara melakukan mogok.

Ideologi humanisme yang dimiliki F.Rahardi memunculkan sikap kritisnya untuk memperjuangkan para korban tragedi 1998. Dalam karyanya Negeri badak(2007), ia menguak tragedi 1998 yang digunakannya sebagai setting waktu. Ia mencoba menggambarkan penderitaan rakyat pada saat itu lewat puisi. Hal serupa juga ditunjukkan dalam cerpen Mogok yang menceritakan bagaimana ayamayam pada suatu desa melakukan aksi mogok bertelur. Aksi tersebut dilakukan lantaran tuntutan produktivitas telur yang banyak oleh majikan mereka tidak diimbangi makanan yang layak. Aksi mogok yang dilakukan ayam-ayam tersebut ditanggapi dengan tindakan-tindakan koersif berupa ancaman-ancaman, bahkan penculikan, yang terakhir adalah seluruh ayam dipotong dan diganti ayam ras. F. Rahardi ingin menggambarkan bahwa hal serupa juga dialami oleh sebagian buruh-buruh di Indonesia. Mereka membentuk serikat buruh untuk menyampaikan aspirasi mereka, tetapi yang mereka terima bukanlah dipenuhinya tuntutan melainkan tindakan koersif. Tindakan tersebut mulai dengan PHK ataupun penculikan dan pembunuhan seperti yang dialami Marsinah pada masa orde baru.

\section{Posisi Pers dan Cerpen-Cerpen Kompas dalam Hegemoni Negara Orde Baru (1966- 1980)}

Praktis antara tahun 1966 sampai dengan awal tahun 1970-an, hampir tidak ada masalah antara pers dengan pemerintah. Pers boleh meliput apapun sejauh pers tidak menentang kekuasaan yang anti-komunis (Oey dalam Hanazaki, 1998:20) Akan tetapi, sejak awal 1970-an, masalah mulai muncul, lambatlaun kebebasan mulai dikekang, terutama menjelang dilaksanakannya pemilu 1971. Secara perlahan musuh politik presiden Soeharto 
mulai muncul, orang-orang yang tidak puas terhadap pemerintahan baru berani berbicara lantang. Peristiwa-peristiwa semacam ini tidak luput dari liputan pers. Liputan yang dilakukan pers ikut menyulut komponen lain untuk menentang pemerintah. Puncaknya meletuslah peristiwa Malari 1974 yang menentang penggunaan produk buatan Jepang. Sejak peristiwa tersebut, pemerintah mulai melakukan kontrol terhadap pers. Pers mulai dianggap membahayakan stabilitas negara. Memang pemerintah Orde Baru telah menciptakan mekanisme kontrol yang efektif terhadap pers. Kontrol itu bisa berupa slogan-slogan, seperti "pers yang bebas dan bertanggung jawab" atau interaksi positif antara pemerintah, pers, dan masyarakat (Luwarso, 1998:27). Untuk memenuhi harapan ini, yang diperlukan bukan saja penggelaran aparatur represif dari negara untuk mengendalikan oposisi dan pembangkangan, tetapi yang tak kalah hebatnya upaya-upaya mengendalikan dan memanipulasi sistem reproduksi ideasional demi meratakan jalan bagi pengoperasian hegemoni makna. Perekayasaan isu menjadi efektif karena kontrol kekuasaan terhadap media massa, sehingga kekuasaan bisa menentukan apa yang boleh dimuat dan tidak boleh dimuat dalam hampir semua media massa resmi melalui budaya telepon, pembinaan, ancaman pembredelan, dan kontrol melalui saham yang ditanamkan di media massa yang bersangkutan (Sudjatmiko, 2000:251). Selain menimpa banyak media massa karena pembredelan besar-besaran oleh pemerintah, Kompas secara langsung juga menerima imbasnya, walaupun tidak dibredel, hanya saja banyak orientasi ideologis yang bergeser.

Hasil penelitian Tjipta Lesmana terhadap harian Kompas menyimpulkan bahwa peristiwa Malari adalah "tonggak sejarah" bagi perubahan orientasi tajuk rencana harian Kompas. Sebelum Malari, Kompas masih idealis dalam hal "menyuarakan hati nurani rakyat" dan melakukan kontrol sosial secara kritis dan berani. Menurut Tjipta Lesmana, fungsi Kompas sebagai "bulldog" (anjing penjaga) berubah drastis menjadi "juru bicara" atau interpreter pernyataan pejabat pemerintah (Abar, 1995:3). Negara dalam rezim Orde Baru adalah negara yang mempunyai kedudukan politik yang kuat atau bahkan sangat kuat dalam berhadapan dengan kekuatan-kekuatan politik masyarakat. Kenyataan ini dibuktikan dengan keberhasilan dan kemampuan negara untuk tidak mempedulikan serta menolak berbagai kritik, protes, serta tuntutan yang datang dari masyarakat sejak awal kebangkitannya. Kedua, dominasi negara atas seluruh unsur-unsur masyarakat yang vokal, termasuk pers yang dapat ditertibkan dan dijinakkan.

Keadaan ini berimpilikasi terhadap posisi pers, sehingga dapat diketahui penyebab perubahan ideologi pers. Pertama, perihal posisi politik pers khususnya Kompas. Posisi pers pada periode 1966-1980 sangat lemah. Hal ini sesuai dengan proposisi tersebut, yakni bahwa pada periode 1966-1980 negara punya kedudukan politik yang kuat dan bahkan sangat kuat, sementara itu kedudukan politik masyarakat lemah. Dalam konteks tatanan politik yang demikian, pers yang juga salah satu unsur masyarakat menjadi lemah kedudukan politiknya. Dalam arti, berbagai kritik yang dilancarkan oleh pers secara terbuka, keras, dan berani tidak berhasil mempengaruhi atau mengubah kehendak-kehendak, kebijakankebijakan serta tingkah laku politik negara.

Kedua, tentang orientasi atau ideologi pers yang pada periode 1966-1974 (hingga peristiwa Malari) lebih populis dan kritis, padahal pers berada dalam tatanan politik dimana negara mempunyai kedudukan politik yang kuat dan sementara kedudukan politik masyarakat lemah. Pers pada kurun waktu tersebut tidak terpengaruh secara orientasi atau ideologi disebabkan posisi negara yang kuat tidak dengan sendirinya membawa negara ke dalam posisi dominasi dalam hubungannya dengan masyarakat sejak awal kebangkitannya tersebut. Seperti digambarkan sebelumnya, bahwa dinamika hubungan negara dan masyarakat melalui tiga tahapan, terlihat betapa untuk mencapai posisi yang dominatif negara 
harus melewati pergumulan politik yang cukup lama, terutama dengan unsur-unsur masyarakat yang vokal yang sejak tumbangnya rezim Orde Lama telah mengalami kebangkitannya yang luar biasa. Proses dominasi negara terhadap seluruh unsur masyarakat baru dapat diselesaikan pada epilog peristiwa Malari, 1974. Periode 19661974 (hingga peristiwa Malari) ini lebih tepat disebut sebagai periode transisi negara menuju ke tahap dominasi yang sempurna. Dan setelah periode transisi tersebut berlalu, di mana negara sudah berhasil mendominasi seluruh unsur masyarakat, maka negara dengan mudah mengkondisikan orientasi pers Indonesia untuk lebih berorientasi terhadap negara.

Berdasarkan uraian di atas, penelitian terhadap cerpen-cerpen surat kabar sangat penting. Sebab apakah cerpen-cerpen yang dimuat dalam harian surat kabar terpengaruh oleh hal tersebut atau justru sebaliknya. Pers yang awalnya bersikap kritis menjadi pers yang bersifat elitbirokratis yang menjadi corong bagi kebijakankebijakan negara.

Walaupun demikian, intervensi pemerintah terhadap karya-karya sastra tetap dapat dirasakan, terutama terhadap genre karya sastra yang bersifat populis seperti prosa dan drama. Bobot karya-karya tersebut diakui oleh masyarakat, tetapi oleh pemerintah dianggap sebagai sesuatu yang berbahaya secara politis, karena dianggap mengancam status-quo kehidupan sosial pada umumnya yang sudah mapan. Sensor yang dilakukan pemerintah berupa pelanggaran resmi dari aparat keamanan, diberlakukannya segala bentuk tekanan terhadap penulis bahkan hingga penahanan. Selain itu, tindakan yang dilakukan adalah melakukan penutupan penerbit yang mempublikasikan karya tersebut. Contoh paling jelas dalam kasus ini adalah kesusastraan yang dihasilkan oleh para bekas anggota Lekra, kasus pelarangan bukubuku Pramoedya Ananta Toer dan penerbit Hasta Mitra. Buku-buku karya Pram dianggap mengandung ideologi komunisme yang menjadi musuh utama negara Orde Baru pada saat itu. Selain itu, terdapat juga pelarangan pementasan drama penyair-dramawan Rendra yang selalu bersikap kritis terhadap pemerintah.

Dalam uraian di atas terlihat bagaimana hubungan antara pengarang atau sastrawan dengan negara. Dalam uraian di atas, terdapat perlawanan pengarang terhadap negara yang bersifat vis a vis, dalam arti perlawanan dilakukan dengan berhadapan langsung dengan negara. Akan tetapi, pada ranah yang berbeda, beberapa pengarang memilih untuk berkarya melalui media massa.Mereka mempublikasikan karya-karya mereka melalui sastra koran. Salah satu bentuk sastra koran adalah cerpen.

Counter hegemoni yang dilakukan cerpen merupakan penyeimbang pers sebagai media massa, dalam hal ini Kompas,yang ikut terintervensi oleh kejadian Malari 1974. Ancaman pembredelan adalah salah satu titik tolak Kompas dalam perubahan ideologinya. Kompas yang semula berideologi humanis dan bersikap kritis terhadap kinerja pemerintah seakan dibungkam, berubah drastis menjadi bersifat elit-birokratis. Suara rakyat kecil yang biasa menghiasi harian Kompas berubah menjadi suara elit birokratis yang berisi kebijakankebijakan pemerintah.

\section{Kesimpulan}

Cerpen memiliki posisi yang unik dalam hubungannya dengan intervensi negara terhadap karya sastra. Cerpen seolah-olah menjadi bagian dari suatu media cetak atau surat kabar dan majalah yang terhegemoni langsung oleh negara, dalam hal ini Kompas, tetapi pada dasarnya cerpen terpisah secara bentuk. Pada posisi demikian, cerpen memiliki keuntunganyakni tidak terhegemoni langsung oleh negara. Akan tetapi, pengarang mempunyai tanggung jawab besar terhadap cerpen yang ditulisnya. Cerpen yang ditulisnya tetap pada kriteria umum dan penyeleksian pihak Kompas. Walaupun demikian, cerpen-cerpen tersebut tetap kritis dalam berbagai bentuk yang dirangkum dengan politisasi cerita tertentu agar lolos dari sensor negara. 
Jurnal Poetika Vol. II No. 1, Juli 2014

\section{Daftar Pustaka}

Abar, Ahmad Zaini. 1995. 1996-1974: Kisah Pers Indonesia. Yogyakarta: LKiS

Ajidarma, Seno Gumira. 2003. Dua Kelamin Bagi Midin: Cerpen Kompas Piliban 1970-1980. Jakarta: Penerbit Buku Kompas.

Al-Barry, M. Dahlan Yacub. 2001. Kamus Sosiologi Antropologi. Surabaya: Indah. Ananda, Yusakh. 2003. "Juara Drum Band". Dalam buku Dua Kelamin Bagi Midin: Cerpen Kompas Pilihan 1970-1980. Editor: Seno Gumira Ajidarma. Jakarta: Penerbit Buku Kompas.

Bagus, Lorens. 1996. Kamus Filsafat. Jakarta: Gramedia Pustaka Utama.

Bourchier, David. 2007. Pancasila Versi Orde Baru. Yogyakarta: Aditya Media.

Budiman, Arief. 1995. "Kebudayaan Materialisme, Egoisme, dan Persaingan (MEP) Serta Cara Menangkalnya".Dalam A. Suryana Sudradjat (ed). 1995. Demokrasi dan Budaya MEP (Materialisme, Egoisme, dan Persaingan). Jakarta: Bina Reka Pariwara.

Damono, Sapardi Djoko. 1984. Sosiologi Sastra: Sebuah Pengantar Ringkas. Jakarta: Pusat Pembinaan dan Pengembangan Bahasa.

Faruk H.T. 1999. Pengantar Sosiologi Sastra : Dari Strukturalisme Genetik Sampai Post Modernisme. Yogyakarta : Pustaka Pelajar.

1988. Strukturalisme Genetik dan Epistimologi Sastra. Yogyakarta: Lukman Offset.

Faruk, Bakdisoemanto, dan Bambang Purwanto. 2000. Perlawanan Atas Diskriminasi Rasial Etnik: Konteks Sosial-Ideologis Kritik Sastra Tionghoa Peranakan. Magelang: IndonesiaTera.

Giddens, Anthoni. 1985. Kapitalisme dan Teori Modern, Suatu Analisis Terhadap Karya Tulis Marx, Durkheim, dan Max Weber, diterjemahkan oleh Suheba
Kramadibrata. Jakarta: Universitas Indonesia Press.

Goldmann, Lucien. 1981. Method in The Sociology of Literature. Oxford: Basil Blackwell Publisher. 1977. Toward A Sociology of The Novel. London: Taristock Publication Limited.

Hanazaki, Yasuo. 1998. Pers Terjebak. Jakarta: Institut Studi Arus Informasi

Harjito. 2002. "Studen Hijo Karya Marco Kartodikromo Analisis Hegemoni Gramscian", Tesis. Yogyakarta : Universitas Gadjah Mada.

Herianto, Ariel. 1998. Masibkah Politik Jadi Panglima? Politik Kesusastraan Indonesia Mutakbir dalam Prisma no.8 th.XVII. Jakarta: LP3S.

Hoare, Quintin dan Geoffrey Nowel Smith. 2000. Antonio Gramsci Sejarah dan Budaya. Terjemahan Ira Puspitorini dkk. Surabaya : Pustaka Promethea.

Junus, Umar. 1986. Sosiologi Sastra: Persoalan, Teori, dan Metode. Kuala Lumpur: Dewan Bahasa dan Pustaka Kementrian Pelajaran Malaysia.

Kusumandaru, Ken Budha. 2003. Karl Marx, Revolusi dan Sosialisme. Yogyakarta: Resist Book.

Lanur, Alex. 1984. "Ideologi Apa Itu?*” dalam Basis no. XXXIII-Februari tahun 1984

1986. Feminisme dan Gerakan Emansipasi dalam Basis no. XXXV-April tahun 1986.

Liddle, R. William. 1992. Partisipasi dan Partai Politik. Jakarta: PT Temprint.

Liftschitz, Mikhail. 2004. Praksis Seni Marx dan Gramsci. Diterjemahkan oleh Ari Widjaja. Jakarta: Alinea.

Luwarso, Lukas. 1998. Wajah Media Massa Kita. Dalam Ery Sutrisno (Ed). Reformasi Media Massa (hlm 25-35). Jakarta: Aliansi Jurnalis Indonesia.

Magnus-Suseno, Frans. Cet. 5. 2001. Pemikiran Karl Marx : Dari Sosialisme Utopis ke Perselisiban Revolusi. Jakarta : 
Gramedia Pustaka Utama.

Cet. 2. 2005. Dalam Baayang-Bayang

Lenin : Enam Pemikir Marxisme dari

Lenin Sampai Tan Malaka. Jakarta :

Gramedia Pustaka Utama.

Mangunhardjana. 1997. Isme-Isme dalam Etika

dari A Sampai Z. Yogyakarta:

Penerbit Kanisius.

Muttahari, Murtadha. 1992. Kritik Islam Terhadap

Faham Materialisme. Jakarta: Risalah Masa.

Oetama, Jacob. 2001. Pers Indonesia. Jakarta: Gramedia Pustaka Utama.

Passe, Zakaria M. 2003. "Pablawan". Dalam buku Dua Kelamin Bagi Midin: Cerpen Kompas Pilihan 1970-1980. Editor: Seno Gumira Ajidarma. Jakarta: Penerbit Buku Kompas.

Patria, Nezar dan Andi Arief. 1999. Antonio Gramsci : Negara dan Hegemoni. Yogyakarta : Pustaka Pelajar.

Piliang, Yasraf A. 2005. Transpolitik: Dinamika Politik di dalam Era Virtualitas. Yogyakarta: Jalasutra.

Pujiharto dan Cahyaningrum Dewojati. 2001.

"Tdeologi Cerpen-Cerpen Koran di Yogyakarta”, Laporan Penelitian. Lembaga Penelitian Universitas Gadjah Mada Departemen Pendidikan Nasional.

Rahardi, F. 2003. "Mogok". Dalam buku Dua

Kelamin Bagi Midin: Cerpen Kompas Piliban 1970-1980. Editor: Seno Gumira Ajidarma. Jakarta: Penerbit Buku Kompas.

Rampan, Korie Layun. 2000. Angkatan 2000

Dalam Kesusastraan Indonesia.

Yogyakarta : Grasindo.

Ratna, Nyoman Kutha. 2004. Teori, Metode, dan

Teknik Penelitian Sastra. Yogyakarta :

Pustaka Pelajar.

Rosidi, Ajip. Ikhtisar Sejarah Sastra Indonesia. 1986. Binacipta: Bandung

Simbolon, Parakitri Tahi. 2003. "Tawanan". Dalam buku Dua Kelamin Bagi Midin: Cerpen Kompas Pilihan 1970-1980. Editor: Seno Gumira Ajidarma.
Jakarta: Penerbit Buku Kompas.

Simon, Roger. 1999. Gagasan Pokok Gramsci. Terjemahan Kamdani dan Imam Baehaqi. Yogyakarta : Pustaka Pelajar.

Stanton, Robert. 2007. Teori Fiksi Robert Stanton (Terjemahan Sugihastuti dan Rossi Abi Al Irsyad). Yogyakarta: Pustaka Pelajar.

Sugiono, Muhadi. 1999. Kritik. Antonio Gramsci Terhadap Pandangan Dunia Ketiga. Yogyakarta : Pustaka Pelajar.

Sudjatmiko, Budiman. 2000. "Represi Melalui Media Massa Pada Masa Soeharto". Dalam Dedy N. Hidayat.(Eds). Pers dalam Revolusi Mei Runtubnya Sebuah Hegemoni (hlm 250-259). Jakarta: PT. Gramedia Pustaka Utama.

Suseno, Frans Magnis. 2002. Agama, Humanisme, dan Masa Depan dalam Basis no 05-06 tahun ke-51. Yogyakarta: Kanisius.

Wellek, Rene \& Austin Warren. 1993. Teori Kesusastraan, diterjemahkan oleh Melani Budianta. Jakarta: Gramedia. 